\title{
Interactions between baculoviruses and entomophagous insects
}

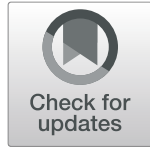

\author{
Mohamed Samir Tawfik Abbas (ID
}

\begin{abstract}
Some laboratory studies revealed that predators can readily attack and consume virus-infected prey with no detrimental effects on their biological parameters. Most tested predacious species did not discriminate between healthy and virus-infected prey. In addition, such predators were found to excrete detectable amounts of polyhedral inclusion bodies for few days that might infect healthy prey. Field studies demonstrated that the population densities and dispersal of the predators were not affected in fields sprayed with entomopathogenic virus formulations. Some laboratory studies stated that egg and larval parasitoids did not discriminate between healthy and virus surface-contaminated or virus-infected hosts. However, some parasitoids did not lay or laid few eggs in virus-infected hosts. Parasitoid adults that laid eggs in virus-infected host larvae could transmit the virus to healthy hosts through the ovipositor. Also, adult parasitoids emerged from virus-infected hosts transmitted the virus to healthy hosts whereas other parasitoids did not transmit the virus.
\end{abstract}

Keywords: Baculoviruses, Nucleopolyhedroviruses, Granuloviruses, Parasitoids, Predators, Entomophagous insects

\section{Background \\ Baculoviruses}

There are more than 1100 species of viruses that infect invertebrates with the majority of infecting insects (Adams 1991). Most of these insect viruses are found in the family Baculoviridae. However, there are insect viruses in 15 other viral families (Hunter-Fujita et al. 1998). Baculoviruses have been used as bio-pesticides in forestry, orchards, and raw crops since the early 1990s with fair success (Inceoglu et al. 2006). A factor that most favors the potential success of viruses is their lack of adverse effects on the environment compared to chemical insecticides. Their major environmental effect is the reduction of insect populations and subsequently may indirectly reduce the populations of entomophagous insects (Fuxa 1990). Hochberg (1991) reported that premature death of parasitoids in virus-infected hosts is the main reason for the negative effect of viruses on parasitoids. In addition, the slow kill and their degradation

Correspondence: samra_mst@hotmail.com

Biological Control Department, Plant Protection Research Institute, Cairo, Egypt due to environmental conditions have limited their use (Inceoglu et al. 2006).

According to Murphy et al. 1995, the International Committee on Taxonomy of Viruses (ICTV) revised the classification of the family Baculoviridae and divided it into two genera: (1) Nucleopolyhedrovirus (NPV) (formerly nuclear polyhedrosis virus) and (2) Granulovirus (GV) (formerly granulosis virus). However, Jehle et al. (2006) and Afolami and Oladunmoye (2017) reported that the Baculoviridae family contains 4 genera: Alphabaculovirus (lepidopteranspecific neocleopolyhedroviruses (NPV)), Betabaculovirus (lepidopteran-specific granuloviruses (GV)), Gammabaculovirus (hymenopteran-specific NPV), and Deltabaculovirus (dipteran-specific NPV). Herniou and Jehle (2007) stated that Baculoviridae contains more identified insect viruses than any other viral family.

\section{Mode of action of baculoviruses}

Baculoviruses have to be ingested by the host (larvae or adults) as occlusion body (OB) forms and then infect the cells of the gut. From these cells, the virus can spread and multiply throughout the other tissues including the fat body, hypodermis, tracheal matrix, epithelial cells,
Springer Open

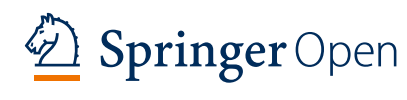

(c) The Author(s). 2020 Open Access This article is licensed under a Creative Commons Attribution 4.0 International License, which permits use, sharing, adaptation, distribution and reproduction in any medium or format, as long as you give appropriate credit to the original author(s) and the source, provide a link to the Creative Commons licence, and indicate if changes were made. The images or other third party material in this article are included in the article's Creative Commons licence, unless indicated otherwise in a credit line to the material. If material is not included in the article's Creative Commons licence and your intended use is not permitted by statutory regulation or exceeds the permitted use, you will need to obtain permission directly from the copyright holder. To view a copy of this licence, visit http://creativecommons.org/licenses/by/4.0/. 
and blood cells. Cell lysis and disintegration of host tissues begin shortly after the formation of OBs (polyhedra in NPV and granulin in GV). Young host larvae die within 2 days whereas older larvae die within 4-9 days (Afolami and Oladunmoye 2017).

\section{Parasitoids and predators}

Parasitoids and predators are among the biological control agents that play an important role, naturally, against agricultural pests infesting field crops, vegetables, fruit trees, and ornamentals. They constitute a considerable part within IPM programs.

\section{A. Interactions between baculoviruses and predators Laboratory experiments}

a. Effect on predators fed on virus-infected prey Abbas and Boucias (1984) reported that the Anticarsia gemmatalis (Hubner) nuclear polyhedrosisvirus (AgNPV) had no direct adverse effects on the pentatomid predator, Podisus maculiventris (Say). Microscope examination and bioassay of tissues extracted from predators fed on AgNPV-infected larvae for 10 days demonstrated that this virus did not replicate in the treated predator. Abbas (1987a) obtained similar results by rearing the predators Calleida decora (F.) (Coleoptera: Carabidae), Nabis capsiformis (Germar) (Hemiptera: Nabidae), and Geocoris punctipes (Say) (Hem.: Lygaeidae) on larvae of A. gemmatalis infected with AgNPV and also by rearing larvae of Chrysoperla carnea Steph. (Neuroptera: Chrysopidae), nymphs and adults of Orius albidipennis (Reut.) (Hem.: Anthocoridae), and adults of Labidura riparia Pallas (Dermaptera: Labiduridae) on NPV-infected larvae of Spodoptera littoralis (Boisd).

De Nardo et al. (2001) reared the predator Podisus nigrispinus (Dallas) exclusively for 3 consecutive generations on A. gemmatalis larvae reared on an artificial diet treated with a commercial formulation of the AgNPV. Their results showed no adverse effects in the first generation on oviposition and survival of the predator. However, adverse effects in the predator population were noticed in the subsequent generations. The authors related such adverse effects to some inert components in the commercial formulation. Different predator species that reared on NPV-infected prey did not suffer deleterious effects (Ruberson et al. 1991; Mahmoud 1992; Fuxa et al. 1993; Heinz et al. 1995; Li et al. 1999).

As presented by Gupta et al. (2013), the developmental period, survival rate, sex ratio, and egg incubation period of the predator Eocanthecona furcellata Wolff. (Hem.: Pentatomidae) reared on different proportions of healthy and NPV-infected Spodoptera litura (F.) did not vary significantly. However, when the proportion of the infected prey exceeded $50 \%$, significant reductions in body weight, fecundity, longevity, and egg hatchability percent of the predator were noticed.

\section{b. Discrimination between healthy and virus-infected} prey Abbas and Boucias (1984) stated that P. maculiventris readily accepted and fed on the virus-infected larvae of $A$. gemmatalis during its nymphal and adult stages. No significant differences were found in the food consumption or development of the predators which were fed healthy versus virus-infected prey. Mahmoud (1992) found that both larvae and adults of the coccinellid predator, Coccinella undecimpunctata L., were found to prey upon NPV-infected $S$. littoralis with no differences in the rate of consumption on healthy and infected prey.

Vasconcelos et al. (1996) reported that the 3 carabid species, Harpalus rufipes De Geer, Pterostichus melanarius Illiger, and Agonum dorsal Pontoppidan, showed no evidence of discrimination between healthy and NPV-infected larvae of their prey, Mamestra brassicae L. Similarly, Casteillejos et al. (2001) found that larvae of Chrysoperla rufilabris Burmeister did not discriminate between healthy and NPV-infected larvae of Spodoptera frugiperda (Smith), whereas, in contrast, adults of Duro taeniatum (F.) (Dermaptera: Forficulidae) directed a greater proportion of its attack toward the infected larvae.

c. Dispersal of virus through predators' feces Abbas and Boucias (1984) reported that both nymphs and adults of $P$. maculiventris fed on AgNPV-infected $A$. gemmatalis larvae excreted intact polyhedral inclusion bodies (PIBs) which were virulent to A. gemmatalis larvae. Adult predators consumed more infected prey than did the 4th instar nymphs and thus were capable of excreting detectable levels of PIBs for 4 days, compared to only 1 day for the nymphs, after feeding on infected prey for $24 \mathrm{~h}$. Young and Yearian (1987) stated that adults of Nabis roseinpennis Reut. that fed on NPVinfected A. gemmatalis larvae excreted infective levels of virus for 10 days with $98 \%$ excreted during the first 2 days after feeding on infected larvae.

Olofsson (1989) found that larvae of Coccinella septempunctata L. fed on NPV-infected larvae of the sawfly, Neodiprion sertifer (Geoffroy) (Hym.: Diprionidae), for 2 days excreted feces containing large quantities of PIBs. Similarly, Mahmoud (1992) reported that the 4th larval instars and adults of C. undecimpunctata that fed on NPV-infected larvae of $S$. littoralis were capable of excreting viable PIBs for 2 and 4 days, respectively. Vasconcelos et al. (1996) stated that the carabids, Harpalus rufipes De Geer, P. melanarius, and A. dorsal, continuously passed infective levels of virus in the soil, in laboratory, for at least 15 days after feeding on NPVinfected larvae of M. brassicae. Casteillejos et al. (2001) reported that a viable virus was detected in the feces of 
Doru taeniatum adults up to 3 days after feeding on NPVinfected larvae of S. frugiperda, and in contrast, the virus was inactivated in the gut of Chrysoperla rufilabris larvae.

\section{Field experiments}

a. Impact of virus on predators Treacy et al. (1997), in two small field trials, found that the population levels of non-target arthropods (18 different non-lepidopteran insects in addition to various spiders) were not adversely affected by the weekly application of NPV at doses up to $2 \times 10^{12} \mathrm{PIBs} / \mathrm{h}$. In addition, Smith et al. (2000) found no differences in the densities and diversities of predators' populations in a cotton field up to 6 days postapplication of NPV against cotton pests.

b. Dissemination of virus by predators Boucias et al. (1987) sprayed $A$. agemmatalis NPV as a bio-control agent against $A$. gemmatalis at a concentration of $2.3 \times$ $10^{11} \mathrm{PIBs} / \mathrm{ha}$ in a soybean field ( 0.9 ha) divided into 8 plots. Four plots were treated with the virus, and the other 4 plots were sprayed with water as a control. The invertebrate fauna was collected biweekly throughout the growing season including predators and phytophagous insects. The presence of AgNPV in predator samples collected from the field was determined by bioassaying predators' homogenates against neonate $A$. gemmatalis larvae. Their results showed that $41 \%$ of the total 2476 predators' homogenates from treated and control plots were found to contain detectable levels of AgNPV that caused mortality among the treated larvae.

Olofsson (1989) studied the transmission of the NPV of the sawfly, $N$. sertifer, during natural epizootics in 4 summer seasons in a pine field. His results showed that the reduviid, Rhinocoris annulatus; the pentatomids, Picromerus bidens (L.), and Troilus luridus Flickr; the mirid, Lygus sp.; and the coccinellid, C. septempunctata, were found to feed on virus-infected $N$. sertifer and transmit the virus. Similarly, Young and Yearian (1990a) carried out an experiment for testing the potential of predators to transmit Heliothis zea (Boddie) NPV in a soybean field. They found that a complex of predators, spiders, Geocoris spp., Orius spp., Nabis spp., reduviid spp., and coccinellid spp., were contaminated, but their role in virus dissemination did not seem to be important.

Groner (1990) listed 18 instances of viruses being dispersed by predators through their feces. Such predators included species belonging to the insect orders Orthoptera, Dermaptera, Heteroptera, Coleoptera, and Hymenoptera. The author claimed that the predators seemed to be little affected by feeding on infected prey due to the more acid in their digestive systems. Vasconcelos et al. (1996) found that the carabids H. rufipes, P. melanarius, and $A$. dorsalis which fed on NPV-infected larvae of $M$. brassica transmitted sufficient levels of virus in the soil to cause low rates of mortality in the populations of the different larval instars of $M$. brassica.

Lee and Fuxa (2000) found that the predator P. macoliventris and the scavengers Sarcophaga bullata (L.) (Dipt.:Sarcophagidae) and Acheta domesticus (L.) (Dipt.: Tachinidae) were capable of transmitting NPV to Trichoplusia $n i(\mathrm{H}$.) larvae at significant rates in a greenhouse experiment. Also, Casteilljos et al. (2001) reported that adults of $D$. taeniatum that fed on virus-infected prey could contaminate the foliage resulting in the transmission of the disease at a low prevalence $(4.7 \%)$ to $S$. frugiperda larvae.

Black (2017), in a soybean field experiment, found that the mirid Lygus lineolaris (Palisto de Beauvois) and the geocorids Geocoris spp. were noticed to feed on NPVinfected larvae of Helicoverpa armigera (H.) and were confirmed to be carriers of the virus. In addition, the reduviids; the coccinellid, Coleomegilla maculate; and the chrysopid larvae were also found crawling and feeding on liquefied larval remains and were capable of transmitting the virus to healthy larvae.

\section{B. Interactions between baculoviruses and insect parasitoids}

a. Discrimination between virus-infected and uninfected hosts Abbas (1987b) found that the egg parasitoid Trichogramma evanescens (Westwood) did not discriminate between NPV surface-contaminated eggs of Spodoptera littoralis, and its progeny developed normally in contaminated and uncontaminated eggs. Similarly, Escribano et al. (2000) found that the egg-larval parasitoid Chelonus insularis Cresson did not discriminate between healthy and NPV surface-contaminated eggs of $S$. frugiperda.

Mahmoud (1992) stated that the larval parasitoid Microplitis rufiventris (Kok.) did not discriminate between healthy and NPV-infected larvae of $S$. littoralis. Jiang et al. (2011) stated that each female of the parasitoid Microplitis pallidipes (Szep.) that developed in SeNPV-infected $S$. exigua larvae was found to oviposit in virus-infected hosts. In contrast, Cotesia glomerata (L.) did not oviposit in GVinfected larvae of Pieris rapae (L.) (Kelsey 1982). Also, Cotesia melanoscelus (Ratz.) females attempted to oviposit greater, significantly, in its uninfected than infected host larvae, Lymantria dispar (L.) (Versoi andYendol 1982). Similarly, the larval parasitoid, Meteorus gyrator (Thunberg) could discriminate between healthy and GV-infected Lecanobia oleracea larvae (Noctuidae) and laid fewer eggs in the virus-infected larvae (Mathews et al. 2004).

\section{b. Transmission of viruses}

Laboratory experiments Irabagon and Brooks (1974) reported that the transmission of baculoviruses occurs 
when the ovipositor, body surface or the gut of the parasitoid becomes contaminated with the virus. Abbas (1987b), Mahmoud (1992), and Hui-Fang et al. (2013) reported that parasitoid females that oviposited in virusinfected larvae were found to transmit infective levels of the virus to healthy ones via ovipositor. Also, adults of the parasitoid Apanteles glomeratus (L.) emerged from GV-infected larvae of $P$. rapae were found to transmit the virus to healthy ones (Levin et al. 1983). Jiang et al. (2011) stated that the adults of Microplitis pallidipes emerged from cocoons which were surface-contaminated with S. exigua NPV could transmit the virus to healthy larvae.

In contrast, the females of the parasitoids Microplitis croceipes (Cresson) and Campoletis sonorensis (Cameron) that oviposited in NPV-infected larvae of Heliothis zea (Boddie) and S. frugiperda, respectively, did not transmit the virus to healthy larvae (Eller et al. 1988 and Escribano et al. 2000), respectively). Also, Meteorus pulchricornis females that emerged from NPV-infected larvae of $S$. litura were not adversely affected and did not transmit the virus to healthy larvae (Nguyen et al. 2005).

Arai et al. (2018) reported that the Ascovirus of Heliothis virescens (Fab.) (HvAV) (belongs to the virus family Ascoviridae) was found to be transmitted by the parasitoid Meteorus pulchricornis (Wesm.) from infected to healthy larvae of Spodoptera litura (F.) through ovipositor. The authors mentioned that this parasitoid is a major vector for HvAV in Japan, but the ingestion of the virus by parasitoid females might affect the progeny of the parasitoid.

Field experiments Young and Yearian (1990b) tested the transmission of Heliothis NPV by Microplitis croceipes females to $H$. virescens larvae in caged plants in a field test. They found that mortality percent from NPV in larvae exposed to virus-sprayed parasitoid females was higher than when the females were previously allowed to oviposit in infected larvae. In addition, Young and Yearian (1989) reported that $M$. croceipes that emerged from NPV-infected larvae of $H$. virescens could transmit the virus, but its role in disseminating the virus in the field was small. In an experiment in a greenhouse cultivated with cabbage, Jiang et al. (2011) found that the population reduction of $S$. exigua was greater by Micropletis pallidipes females carrying SeNPV (82.3$89.7 \%$ ) than by females without virus (59.5-62.4\%).

In greenhouse trials with GV against Lacanobia oleraceae larvae in tomato plants, Mathews et al. (2004) found that Meteorus gyrator was noticed to discriminate between healthy and infected host larvae. In addition, the parasitoid that transmitted the virus at low levels significantly increased total host mortality and decreased the damage in tomato fruits when combined with the virus.

\section{c. Development and survival of parasitoids in infected hosts} Irabagon and Brooks (1974) reported that the late exposure of the baculovirus-infected host larvae to the parasitoids increased the percentage of successful development of the parasitoids. In this respect, Hochberg (1991) found that when there was either no interval or an insufficient interval between parasitism and virus inoculation, the number of eggs deposited by the parasitoid female was unaffected, but the parasitoids could not complete development because the larvae die of viral infection quickly and fewer parasitoids emerge from the host.

Beegle and Oatman (1974) reported that larvae of the parasitoid Hyposoter exiguae (Viereck) inside Trichoplusia $n i$ larvae infected with NPV prior to parasitism died when their host died from infection. Hutchkin and Kaya (1983) conducted a survey of several parasitoids for their ability to develop to pupae in virus-infected hosts. They found that the tachinid Compsilura concinnata (Meigen), the two ichneumonids Campoletis sonorensis and Hyposoter exiguae, and the braconid Cotesia marginiventris developed to pupae in the armyworm, Pseudaletia unipuncta, infected with either NPV or GV. However, Chelonus insularis died when its host, P. unipuncta, infected with NPV or GV died, while the braconid Glyptapantele smilitaris (Walsh) died in NPV-infected P. unipuncta before the mortality of its host. In addition, $H$. exiguae, $C$. insularis, and C. marginiventris developed to pupae in GV-infected S. exigua larvae.

Abbas (1987b) found that the ecto-larval parasitoid Bracon brevicornis (Wesm.) developed successfully on its host, Heliothis armigera treated with NPV $24 \mathrm{~h}$ before exposure to the parasitoid females. When parasitism occurred $48 \mathrm{~h}$ post-larval infection, only $24.6 \%$ of the parasitoid's progeny developed to adults. However, all parasitoid's progeny died when the host larvae were parasitized 3, 4, or 5 days post-infection. Eller et al. (1988) recorded a high mortality rate in Microplitis croceipes larvae when its host larvae, S. exigua, died from NPV infection.

Murray et al. (1995) mentioned that the larval parasitoids Meteorus demoliter (Wesm.), Cotesia kazak (Telenge), and Hyposoter didymator (Thunberg) required 3 days before the treatment of their host, $H$. armigera, larvae with NPV to complete their development successfully. Kunimi et al. (1999) came to almost similar results as they found that infection of Pseudaletia separata Walker with the GV of Pseudaletia unipuncta (Haworth) (PuGV) negatively affected the development and survival of its larval parasitoid, Cotesia kariyai (Watanabe). No parasitoid larvae emerged from virus-infected host larvae when the 2nd and 3rd larval instars were infected and then exposed 
to the parasitoid in the 4th instar. Also, the parasitoid larvae could not develop in the virus-infected hosts when the 4th instar larvae were simultaneously parasitized and virus-infected.

Similarly, Escribano et al. (2000) found that all S. frugiperda larvae that were treated with a lethal dose of SfMNPV were unsuitable for the development of the egg-larval parasitoid Chelonus insularis. Also, the larval parasitoid, Campoletis sonorensis, did not survive in host larvae treated with the same virus immediately after parasitism, but its survival was possible with a 2-day delay between parasitism and viral infection. Furthermore, the percentage of parasitoid emergence increased significantly as the interval between parasitism and virus-infection increased. Mathews et al. (2004) reported that the survival of Meteorus gyrator within its host, Lacanobia oleraceae, infected with a GV increased as the time between parasitism and infection increased. No parasitoids could develop when parasitism occurred before GV infection whereas infection after parasitism had no effect on the larval or pupal developmental periods.

Nguyen et al. (2005) found that survival of the developmental stages and the adults of Meteorus pulchricornis emerged from NPV-infected $S$. exigua larvae was adversely affected when the larvae were exposed to high doses of the virus 1-3 days post-parasitism. Also, Rabie et al. (2010) stated that NPV-infected Mamestra brassica caused deleterious effects to the parasitoid Habrobracon hebetor Say. This deleterious effect was dependent on the interval between viral-infection, parasitism timing, and the dose of virus. Very few adult parasitoids could emerge from parasitized hosts treated with 180 PIBs/ $\mathrm{mm}^{2}$ of the diet when exposed to the parasitoid $72 \mathrm{~h}$ post-infection. However, Cai et al. (2012) mentioned that the survival rate of adults of Microplitis bicoloratus Chen emerged from $S$. exigua larvae treated with SeMNPV decreased with increasing virus doses against the $2^{\text {nd }}$ to 4th larval instars.

Azam et al. (2016) treated the 2nd instar larvae of $S$. litura which developed from eggs parasitized with the egg-larval parasitoid Chelonus inanitus with a GV. Their results showed that percentages of the emergence of the parasitoid larvae from the host larvae as well as their pupation rate and adult emergence were significantly lower compared to those from the uninfected ones.

\section{d. Effect on parasitoid adults fed on virus}

The longevity of parasitoid female adults of Bracon brevicornis fed on honey or a mixture of honey and NPV $\left(10^{3}\right.$ PIBs) 1:2 was not significantly affected (34.5 and 33.3 days, respectively) (Abbas 1987b). Hui-Fang et al. (2013) reported that the progeny of Meteorus pulchricornis female which ingested S. exigua NPV was significantly affected at
1 and 2 days post-ingestion. The average number of the offspring of treated females was 2.6 cocoons/host larva compared to 4 cocoons for the control female (fed on honey only). However, no significant differences were observed in the number of produced cocoons/host between treated and control females at 3 or 4 days post-ingestion.

\section{e. Effect of parasitism on host susceptibility to virus infection}

Eller et al. (1988) found that when the larvae of H. zea were exposed to Microplitis croceipes females and then infected with HzMNPV, the rate of virus-induced mortality decreased with the increase of host age at the time of infection. The rate of pupated H. zea larvae as well as the cocoon formation of $M$. croceipes increased with the increase of host age at infection for both parasitized and unparasitized larvae. Santiago-Alvarez and Caballero (1990) noticed decreased virulence of GV of Agrotis segetum (Denis) to larvae parasitized with Apanteles telengi compared to unparasitized larvae. However, there was no difference in the virulence of GV between larvae parasitized with Campoletis annulatus and unparasitized ones.

Murray et al. (1995) reported that the $\mathrm{LD}_{50}$ of $H$. armigera NPV for $H$. armigera larvae was higher in larvae parasitized with Microplitis demolitor (Wilkenson) than in unparasitized ones. Washburn et al. (2000) found that Manduca sexta (L.) larvae infected with Autographa californica (Speyer) NPV died more rapidly and at higher rates when they were parasitized by Cotesia congregate (Say). However, Escribano et al. (2001) reported that the virulence of NPV to unparasitized larvae of S. frugiperda did not differ from that to larvae parasitized with Chilonus insularis. Mathews et al. (2004) reported that the percentage of mortality of GVinfected Lecanobia oleraceae larvae was significantly higher when a combination of the larval parasitoid Meteorus gyrator and the virus was used compared to either the virus or the parasitoid alone. Similarly, Cai et al. (2012) found that mortality percent of $S$. exigua larvae was significantly higher (more than $80 \%$ ) when co-exposed to the virus, SeMNPV and the parasitoid Microplitis bicoloratus compared to the virus alone regardless of the virus doses or the timing of virus treatment. Hui-Fang et al. (2013) found that when the 3rd instar larvae of S. exigua were exposed to SeMNPV and Meteorus pulchricornis simultaneously, differences in virus-induced mortality varied in parasitized and unparasitized larvae according to virus concentration. Parasitism, significantly, increased the mortality in larvae infected at concentrations of $10^{5}, 10^{6}$, or $10^{7} \mathrm{PIBs} / \mathrm{ml}$ compared to unparasitized ones. However, at the concentration of $10^{3}$ $\mathrm{PIBs} / \mathrm{ml}$, parasitized larvae were less susceptible to virus infection than unparasitized ones. 


\section{Discussion}

Insect predators can attack and consume virus-infected prey with no detrimental effects on their biological parameters, and, in addition, they excrete detectable amounts of the virus for few days. Laboratory studies showed that predators that offered healthy and pathogen-infected prey showed lower preference (Young and Yearian 1990a), higher preference (Pell and Vandenberg 2002) and no preference (Thomas et al. 2006) to infected prey. Field experiments revealed that the predators can disseminate the virus in the field (Vasconcelos et al. 1996; Young and Yearian 1987; Treasy et al. 1997; Boucias et al. 1987; Black 2017). The predators seem to be little affected by feeding on virus-infected prey due to the more acid in their digestive system (Groner 1990). However, the predators Nabis spp., Reduviid spp., Geocoris spp., Orius spp., coccinellids, and spiders were reported to be vectors of insect viruses in the field, but their significance in inducing epizootics was determined to be minimal (Roy and Holt 2008).

Parasitoids may become carriers of virus by emerging from infected hosts, application of virus- commercial products or by adults feeding or depositing eggs in infected hosts (Raimo et al. 1977). Adult parasitoids may accept virus-infected hosts for oviposition and the parasitoid immatures may complete development in the infected hosts or undergo deleterious effects. Such deleterious effects vary depending on the period between infection and parasitism, the age of infected host and the dose of the virus (Young and Yearian 1990a; Rabie et al. 2010). Combination of a parasitoid and NPV in the field caused population reductions of the target pest than using the virus alone (Jiang et al. 2011), or increased the total mortality of the pest and reduced the damage of the plants (Mathews et al. 2004).

From the data obtained in this review article, it can be claimed that the interactions between baculoviruses and the other natural enemies of insect pests (predators and parasitoids) seem to be complicated. The predators mostly accept and feed on virus-infected prey that may result in decreasing the population of the virus in the field. On the other hand, the predators proved to disseminate the virus in the field through their feces that may result in the increase of the virus efficiency. As for parasitoids, they mostly cannot complete their development inside or on the virus-infected hosts which may lead to the reduction of their population in the field. In the meantime, adult parasitoids can disseminate the virus in the field, mechanically, by the mouth parts after feeding on infected hosts (the ecto-parasitoids) or by the ovipositor after parasitizing infected hosts.

In conclusion, the interaction between the virus and the parasitoids seems to be in favor of the virus while it seems to be in favor of both the virus and the predator. However, further field studies should be done to spot light on the combined effects of such biological control agents against insect pests.

\section{Abbreviations}

NPV: Nucleopolyhedrovirus; GV: Granulovirus; OBs: Occlusion bodies; PIBs: Polyhedral inclusion bodies

\section{Acknowledgements \\ Not applicable}

Author's contributions

Single author. The author read and approved the final manuscript.

Funding

Not applicable

Availability of data and materials

The review article presented the main aims concluded in the title.

Ethics approval and consent to participate

Not applicable

Consent for publication

Not applicable

Competing interests

The author declares that there are no competing interests

Received: 30 April 2020 Accepted: 6 August 2020

Published online: 12 August 2020

\section{References}

Abbas MST (1987a) Interaction between nuclear polyhedrosis virus, host and predators. Zeitschrift fur Pflanzenkrankheiten und Pflanzenschutz 95(6):606610

Abbas MST (1987b) Interaction between host, egg and larval parasitoids and nuclear polyhedrosis virus. Bull. ent. Soc. Egypt. Econ. Ser. 16:133-141

Abbas MST, Boucias DG (1984) Interaction between nuclear polyhedrosis virus-infected Anticarsiagemmatalis larvae (Lep: Noctuidae) and predator, Podisusmaculiventris (Hemiptera: Pentatomidae). Environ. Entomol. 13(2): 599-602

Adams JR (1991) Introduction and classification of viruses of invertebrates. In: Adams JR, Bonami JR (eds) Atlas of invertebrate viruses. CRC Press, Inc. Boca Raton, Fl, pp 1-8

Afolami OI, Pladunmoye MK (2017) Baculoviruses: emerging frontiers for viral biocontrol of insect pests of agricultural importance. J. Advances in Microbiology 5(4):1-7 Article no. JAMB. 35927

Arai E, Ishii K, Sagawa S, Makiyama N (2018) An Ascovirus isolated from Spodopteralitura transmitted by Meteoruspulchricornis. J. General Virology 99: 574-584

Azam A, Kunimi Y, Inoue MN (2016) Effect of a granulovirus infection of Spodopteralitura larvae on development of Chelonusinanitus. Appl. Entomol. and Zoology 51(3):479-488

Beegle CC, Oatman ER (1974) Differential susceptibility of parasitized and nonparasitized larvae of Trichoplusiani to a nuclear polyhedrosis virus. J. Inverteb. Pathol. 24:188-195

Black J (2017) Horizontal transmission of Helicoverpaarmigera NPV in soybean fields infested with Heliothiszea. M.Sc. Thesis, University of Arkansas, USA, p 105. http://scholarworks.vark.edu/etd/2533

Boucias DG, Abbas MST, Tathbone L, Hostettler N (1987) Predators as potential dispersal agents of the nuclear polyhedrosis virus of Anticarsiagemmatalis (Lep: Noctuidae) in soybean. Entomophaga 32(1):97-108

Cai Y, Fan J, Sun S, Wang F, Yang K, Li G, Pang Y (2012) Interspecific interaction between Spodopteraexigua nucleopolyhedrovirus and Microplitisbicoloratus. J. Econ. Entomol. 105(5):1503-1508

Casteillejos V, Garsia L, Cisneros J, Goulson D, Williams T (2001) The potential of Chrysoperlarufilabris and Dorutaeniatum as agents for dispersal of Spodopterafrugiperda nucleopolyhedrovirus in maize. Entomologia Experimentaliset Applicata 98:353-359

De Nardo EA, Maia AHN, Watanabe MA (2001) Effect of formulation of Anticarsia gemmatalis nucleopolyhedrovirus on the predator, Podisus nigrispinus using the fertility life table parameters. Environ. Entomol. 30(6):1164-1173 
Eller FJ, Boucias DG, Tumlinson JH (1988) Interaction between Microplitis croceipes and a nuclear polyhedrosis virus of Heliothis zea. Environ. Entomol. 17(6):977-982

Escribano A, Williams T, Goulson D, Caballero P (2000) Parasitoid-pathogen-pest interactions of Chelonusinsularis, Campoletissonorensis and a nucleopolyhedrovirus in Spodoptera frugiperda larvae. Biological Control 19(3):265-273

Escribano A, Williams T, Goulson D, Chapman W, Caballero P (2001) Consequences of interspecific competition on the virulence and genetic composition of a nucleopolyhedrovirus in Spodoptera frugiperda larvae parasitized by Chelonus insularis. Biocontrol 11:449-462

Fuxa JR (1990) New directions for insect control with baculoviruses. In: New directions in biological control: alternatives for suppressing agricultural pests and diseases (R.Baker and Dunn Eds). Alan R. Liss, New York, pp 93-113

Fuxa JR, Richter AR, Strother NS (1993) Detection of Anticarsia gemmatalis nuclear polyhedrosis virus in predator arthropods and parasitoids after viral release in Louisiana soybean. J. Entomol. Sci. 28:51-60

Groner A (1990) Safety of non-target invertebrates to baculoviruses. In: Laird M, Lacey LA, Davidson EW (eds) Safety of microbial insecticides. CRC Press, Baco Raton, pp 177-202

Gupta R, Gani M, Jastrotia P, Srivastava K (2013) Development of the predator Eocantheconafurcellata (Pentatomidae) on different proportions of nucleopolyhedrovirus-infected Spodoptera litura larvae and potential for predator dissemination of virus in the field. Bio-Control 58:543-552

Heinz KM, McCutchen BF, Herrmann R, Parrella MP, Hammock BD (1995) Direct effects of recombinant nuclear polyhedrosis virus on selected non-target organisms. J. Econ. Entomol. 88:259-264

Herniou EA, Jehle JA (2007) Baculovirus phylogeny and evolution. Curr. Drug Targets 8:1043-1050

Hochberg ME (1991) Extra-host interactions between Apanteles glomeratus and a baculovirus for larvae of Pieris brassicae. J. Animal Ecology 60:65-77

Hotchkin PG, Kaya HK (1983) Interaction between two baculoviruses and several insect parasitoids. Canad. Entomologist 115(7):841-846

Hui-Fang GC, Wan-Fang Z, Liu B (2013) Interaction between Meteorus pulchricornis and Spodoptera exigua multiple nucleopolyhedrovirus. J. Insect Science 13(12): 1-12

Hunter-Fujita FR, Entwhistle PF, Evans HF, Crook NE (1998) Characteristics of insect pathogenic viruses. In: Hunter-Fujita FR, Entwhistle PF, Evans HF, Crook NE (eds) Insect viruses and pest management. John Wiley and Sons, New York, NY, pp 7-26

Inceoglu AB, Kamita SG, Hammock BD (2006) Genetically modified baculoviruses: a historical overview and future outlook. Adv. Virus Res. 68:323-360

Irabagon TA, Brooks TM (1974) Interaction of Campoletissonorensis and nuclear polyhedrosis virus in larvae of Heliothis virescens. J. Econ. Entomol. 67:229-231

Jehle JA, Blissard GW, Bonning BC, Cory JS, Herniou EA, Rohrmann GF, Theilmann DA, Thiem SM, Vlak JM (2006) On the classification and nomenclature of baculoviruses: a proposal for revision. Arch.

Jiang J, Zeng A, Ji X, Wan N, Chen X (2011) Combined effect of nucleopolyhedrovirus and Microplitis pallidipes for the control of Spodoptera exigua. Pest Management Science 67:705-709

Kelsey, J.M. 1982. $11^{\text {th }}$ International Conf. in Entomology, Vienna, 4: 790

Kunimi Y, Mizutani N, Wada S, Nakai M (1999) Granulovirus-infected larvae of Pseudalatia separata (Lep.:Noctuidae) produce factor(s) toxic to Cotesia kariyai. Appl. Entomol. and. Zoology 34(2):241-250

Lee Y, Fuxa JR (2000) Ingestion and defecation of nucleopolyhedrovirus by scavengers and predatory arthropods. Environ. Entomol. 29:950-957

Levin DB, Laing JE, Jaques RP, Corrigan JE (1983) Transmission of the granulosis virus of Pieris rapae by the parasitoid Apanteles glomeratus. Environ. Entomol. 12:166-170

Li J, Heinz KM, Flexner JL, McCutchen BF (1999) Effects of recombinant baculoviruses on three non-target heliothine predators. Biol. Control. 15:293-302

Mahmoud, Basma A. 1992. The role of some Spodoptera littoralis parasitoids and predators as distributers of bacterial and viral insecticides. M.Sc. Thesis, Fac. Agric., Cairo University, $105 \mathrm{pp}$.

Mathews HJ, Smith I, Bell HA, Edwards JP (2004) Interaction between the parasitoid Meteorus gyrator (Braconidae) and a granulovirus in Lacanobia oleraceae (Lep.:Noctuidae). Environ. Entomol 33(4):949-957

Murphy, F.A.; Bishop, D.H.L.; Ghabrial, S.A.; Jarvis, A.W; Martelli, G.P.; Mayo, M.A. and Summers, M.D. (Eds.) 1995. Virus taxonomy-the classification and nomenclature of viruses: 6th Report of the International Committee on Taxonomy of Viruses, Springer-Verlag, New York.
Murray DAH, Mansour CJ, Teakle RE, Rhynne KD, Bean JA (1995) Interactions between nuclear polyhedrosisvirus and three larval parasitoids of Heliothis armigera. J. Australian Entomol. Soc. 34:319-322

Nguyen DH, Nakai M, Takatsuka J, Okino S, Ishii T, Kunimi Y (2005) Interaction between nucleopolyhedrovirus and Meteorus pulchricornis in the larvae of Spodoptera litura. Appl. Entomol. and Zoology 40:325-329

Olofsson E (1989) Transmission agents of the nuclear polyhedrosis virus of Neodiprion sertifer (Hym.:Diprionidae). Entomophaga 34(3):373-380

Pell J, Vandenberg J (2002) Interactions among the aphid Diuraphis noxia, the entomopathogenic fungus Paecilomyces fumosoroseus and the Coccinellid Hippodamia convergens. Biocontrol Sci. Technol. 12:217-224

Rabie MM, Seraj AA, Talaei HR (2010) Interaction between MbMNPV and Habrobracon hebetoron larvae of Spodoptera exigua. Biocontrol Science and Technology 20(10):1075-1078

Raimo B, Reardon RC, Podgwaite JD (1977) Vectoring gypsy moth nuclear polyhedrosis virus by Apanteles melanoscelus [Hym.: Braconidae]. Entomophaga. 22:207-215

Roy M, Holt RD (2008) Effects of predation on host-pathogen dynamics in SIR models. - Theor. Popul. Biol. 73:319-331

Ruberson JR, Young SY, King TJ (1991) Suitability of prey infected by nuclear polyhedrosis virus for development, survival and reproduction of the predator Nabis roseipennis. Environ. Entomol. 20:1475-1479

Santiego-Alvarez C, Caballero P (1990) Susceptibility of parasitized Agrotis segetum larvae to a granulosis virus. J. Inverteb. Pathol. 56:128-131

Smith CR, Heinz KM, Sansone CG, Flexner JL (2000) Impact of baculovirus application on target heliothines and non-target arthropods in cotton. Biol. Control 19:201-214

Thomas, M. B. et al. 2006. Trophic and guild interactions and the influence of multiple species on diseases. In: Trophic and guild in biological interactions control. Springer, pp. 101-122.

Treasy, M.F.; All, J.N. and Kukel, C.R. 1997. Invertebrate selectivity of recombinant baculovirus: case study on gene-inserted Autographa californica NPV: 57-68: In New Developments in Entomology (K. Bondari, ED), London.

Vasconcelos SD, Williams T, Hails RS, Cory JS (1996) Prey selection and baculovirus dissemination by carabid predators of Lepidoptera. Ecological Entomology 21:98-104

Versoi PL, Yendol WG (1982) Discrimination by the parasite, Apanteles melanoscelus, between healthy and virus-infected gypsy moth larvae. Environ. Entomol. 11:42

Washburn JO, Hass-Stepleton EJ, Tan FF, Volkman LE (2000) Coinfection of Manduca sexta larvae with polydnavirus from Cotesia congregate increases susceptibility to fatal infection by Autographa californica nucleopolyhedrovirus. J. Insect Physiology 46:179-190

Young SW, Yearian WC (1987) Nabis roseipennis adults (Hem.:Nabidae) as disseminators of nuclear polyhedrosis virus to Anticarsia gemmatalis larvae (Lep.: Noctuidae). Environ. Entomol. 16:1330-1333

Young SW, Yearian WC (1989) Nuclear polyhedrosis virus transmission by Microplitis croceipes adult females reared in infected Heliothis virescens larvae. J. Entomol. Sc. 24:500-506

Young SW, Yearian WC (1990a) Contamination of arthropod predators with Heliothis NPV after Elcar application to soybean for control of Heliothis spp. J. Entomol. Sci. 25:486-492

Young SW, Yearian WC (1990b) Transmission of nuclear polyhedrosis virus by the parasitoid, Microplitis croceipes to Heliothis virescens on soybean. Environ. Entomol. 19:251-256

\section{Publisher's Note}

Springer Nature remains neutral with regard to jurisdictional claims in published maps and institutional affiliations. 